\title{
EAFT Summit 2018
}

\section{(Spanyolország, San Sebastian, Kursaal Congress Centre, 2018. november 22-23.)}

\author{
Klenk Márk \\ E-mail:klenky1990@gmail.com
}

2018. november 22-én és 23-án San Sebastiánban “3M4Q: Making, Managing, Measuring Terminology. In the pursuit of Quality" (A terminológia elóállitása, menedzselése és mérése a minőség szolgálatában) címmel rendezték meg az European Association for Terminology (EAFT) csúcstalálkozóját. A találkozó lehetôséget biztosított a tapasztalatcserére a terminológia területén tevékenykedő intézmények, kutatók és oktatók számára. A konferencia az EAFT, valamint a fennállásának negyvenedik évfordulóját ünneplő UZEI (Baszk Terminológiai és Lexikográfiai Központ) szervezésében valósult meg, összesen hat szekcióban.

A programot Jon Etxabe az UZEI elnöke, Henrik Nilsson, az EAFT elnöke, valamint Bingen Zupiria, a Baszk kormány kultúráért és nyelvpolitikáért felelős minisztere nyitotta meg. Az előadások nyelve az angol, a francia és a baszk nyelv voltak, a baszk résztvevők előadásaikat baszk nyelven tartották meg. A rendezők konferenciatolmácsok segítségével gondoskodtak az előadások követhetőségéről.

A kétnapos konferencia előadásai a következő hat szekció köré szerveződtek: 1. A terminológiai munka tervezése, 2. A terminológiai munka módszerei I., 3. A terminológus feladatai, szerepkörei, 4. A terminológiai munka módszerei II., 5. A terminológia terjesztése, 6. A terminusok sikerességének mérése felé vezető úton.

Az első szekció a terminológiai munka tervezése címet viselte, a szekcióban összesen négy előadás hangzott el. Az első előadó Araceli Diaz de Lezana volt a Baszk kormány képviseletében, előadásában bemutatta a kormány által promotált terminológiai munka fázisait, valamint az eddig elért sikereket. 1999-ben fogadták el a baszk nyelv használatát előmozdító General Plan for Promoting Basque Language Use dokumentumot, majd 2001-ben létrehozták terminológiai adatbázisukat (EUSKALTERM). Ez idáig összesen 58 különböző területeket (például: egészségügy, oktatás) lefedő terminológiai szótárat tettek publikussá annak érdekében, hogy a baszk nyelv használatát előmozdítsák. A szekció második előadója Donncha Ó Cróinín volt, aki az Ír Terminológiai Bizottság és az európai terminológia kapcsolatáról beszélt. Céljuk az ír nyelvü terminológia

Hivatkozás: Klenk M. 2019. EAFT Summit 2018 (Spanyolország, San Sebastian, Kursaal Congress Centre, 2018. november 22-23.) Forditástudomány 21. évf. 2. szám. 101-105. DOI: https://doi.org/10.35924/fordtud.21.2.7 
fejlesztése, kialakítása és fejlesztése, annak érdekében, hogy az ír nyelv a modern társadalomban is kommunikációs eszközként szolgálhasson. Az elfogadott terminusokat adatbázisukban, a tearma.ie oldalon teszik elérhetővé. A szekció harmadik előadója Albina Auksoriūte, a Lietuvių Kalbos Institutas képviseletében mutatta be a Litvániában zajló terminológiai munkát. Terminológiai adatbázisukat (Term Bank of the Republic of Lithuania) 2003-ban hozták létre, ami az állami intézmények közös információs rendszereként szolgál azóta is, felügyeletét a Litván nyelvért felelős államtitkár látja el, több mint 245 ezer terminust tartalmaz. Kiemelt figyelmet kapott a szekció utolsó előadója Violina Stamtcheva, aki az EP Terminológiai Koordinációs egységének képviseletében mutatta be a IATE 2 terminológiai adatbázist. Az új adatbázisban kiszélesedtek a keresési lehetőségek, a keresés már nem csak a terminus adatmezőben lehetséges. Újdonság, hogy a honlapon valós idejü statisztikákat is megtekinthetünk, akár az egyes nyelvekre lebontva. Belső felhasználók számára fejlesztették az importálási lehetőségeket, rendelkezésükre áll terminológiai kivonatoló rész is, valamint jövő év elején az adatok frissítésének és karbantartásának érdekében, egy projektmenedzsment modult is implementálni terveznek.

A második szekció előadásai a terminológiai módszerei köré szerveződtek. $\mathrm{Az}$ első előadást Claudio Grimaldi a milánói Università Cattolica del Sacro Cuore PhD hallgatója, a Realiter kutatócsoport tagja tartotta. Bemutatta a hálózat munkásságát, melyben a neolatin nyelvű országok terminológiával, terminográfiával, valamint terminológiai harmonizációval foglalkozó kutatóit és intézményeit próbálják összefogni. Eduards Cauna a Lett Tudományos Akadémia Terminológiai Bizottságának képviselője mutatta be az országában végzett terminológiai munkát. A Bizottság célja a lett nyelvü terminológia szisztematikus fejlesztése, a szabályozások folytán azonban a közérdekü ügyekben ki kell kérniük a nyilvánosság véleményét az őket érintő terminológiai megoldásokkal kapcsolatban. Ennek érdekében online felületen fórumot biztosítanak a végfelhasználók számára ahhoz, hogy véleményt nyilvánítsanak az újonnan megalkotott terminusokkal kapcsolatban. A szekció záró előadója Mojca Žagar Karer, a szlovén Fran Ramovš Nyelvtudományi Intézet munkatársa volt. Az Intézet terminológiai csoportjának legfontosabb feladata a különböző doméneket felölelő terminológiai szótárak készítése, majd azok nyomtatásban és online letölthető formában való elérhetővé tétele Terminologišče nevü weboldalukon, valamint a Fran nevü portálon. Eddig 15 ilyen szótárat állítottak össze különböző területeken (például: robotika, jog, várostervezés), a legtöbb bejegyzés angol-szlovén nyelvpárban születik, de francia és német nyelvü adatokkal is rendelkeznek. 2013-ban bővítették a szolgáltatásaikat és terminológiai konzultációs szolgálatként is müködnek, évente több mint 60 megkeresést kezelnek, a válaszokat honlapjukon is publikálják.

A harmadik szekció előadói más-más szempontból a terminológus szerepét járták körül. Az első előadók Petra Drewer, Donatella Pulitano valamint Tom Winter voltak. Elöadásukban röviden bemutatták a DTT (Deutscher Terminologie-Tag / German Association for Terminology), DIT (Deutsches Institut für Terminologie / German Institute for Terminology), továbbá a RaDT (Rat für Deutschsprachige Terminologie / Council for German-Language Terminology) szervezeteket. Hangsúlyozták, hogy a terminológus munkájának a köz- 
pontjában a fogalom áll, fogalmi rendszerekkel dolgozik és ezek a fogalmi rendszerek segítenek neki megérteni a feldolgozandó területet, tisztázni a fogalmak közötti kapcsolatokat. A fogalmak és fogalmi rendszerek ábrázolására gráfokat használhatunk, ezek azonban különböznek az ontológiáktól, mert azok a gépek számára teszik értelmezhetővé a fogalmakat, reprezentálják a világot. Felhívják rá a figyelmet, hogy a terminológus szerepe változóban van, a nyelv és a tudás között funkcionál referenciaemberként. Manapság már egyre kevésbé a fordítók a terminológia elsődleges felhasználói, az új terminusokra azonnal van szükség, és nem feltétlenül egy egész domén kidolgozása a cél, hanem csak a felmerülő kérdésekre kell választ adni. A terminológia felhasználása eddig inkább fordításalapú volt, mára azonban rengeteg területen megjelenik iránta az igény. Fontosnak bizonyul például a chatbot szoftverek használatakor, a keresőmotorok optimalizálásakor, a beszédfelismerésben, vagy a szerzői támogatásban (authoring support). A terminológusnak így már több mindenhez kell értenie, többre van szüksége, mint terminológiaelméleti tudásra. Fontos számára az eszközök és különböző felhasználási területek ismerete, használatuk mikéntjének megértése is. A szekció következő előadója Tamás Dóra Mária volt (OFFI Zrt., ELTE BTK FTT), aki Hungarian legal terminology in education and practice című előadásában előadásában a terminológus szerepkörét körbejárva rámutatott arra, hogy a terminológus koordinátorként, szervezőként kell, hogy müködjön. Röviden bemutatta az OFFI fordítási tevékenységét, az ott zajló munkát és annak módszereit. Kitért az OFFI terminológiai adatbázisának bemutatására, az OFFI és az ELTE együttmüködési projektjeire, valamint a magyar terminológusképzés helyzetére. A szekció utolsó előadója Etienne Quillot volt, a General Delegation for the French Language and in languages of France munkatársa. A náluk folyó terminológiai munka során a terminológus feladata a 19 szakértői csoport koordinálása és irányítása. A terminológus segíti a szakértőket, priorizál a feladatok közt, közvetít valamint formába önti a kérdéseiket, feladata leginkább a megértés elősegítése, a közös nevező megtalálása.

A negyedik szekció előadásai, a második szekcióhoz hasonlóan, a terminológiai módszereivel foglalkoztak. Luis González a DG Trans spanyol nyelvi osztályának képviseletében mutatta be a Terminesp adatbázisát. Előadásában kiemelte, hogy a terminológia fontos szerepet játszik az intézményi fordítók (EU) munkájában. Előadásában hangsúlyozta, hogy az egyes adatbázisok elszigetelten, a mezőgazdaságban használt silókként állak egymás mellett, kevés a kapcsolat közöttük. Ezen információs silók között kapcsolatot teremtve azonban rengeteg lehetőség nyílna meg a felhasználók előtt. A szekció következő előadója Nina Lewau volt, a svéd Migrációs Hivatal munkatársa. A hivatal munkájának rövid bemutatása után kitért Enterprise architect-ként végzett munkájának bemutatására. Munkája során kapcsolatot tart a Hivatal osztályaival, valamint az egyéb svéd hatóságokkal, annak érdekében, hogy egymás munkáját megfelelő módon segíteni tudják. Terminológusokkal, nyelvészekkel és IT szakemberekkel együttmüködve sokkal szélesebb körü látókörre és probléma-megoldási készségre tett szert.

Az ötödik szekció első előadója Cristina Valentini volt, a WIPO (World Intellectual Property Organization, Szellemi Tulajdon Világszervezete), az ENSZ szervének képviseletében. Előadásában a WIPO Pearl nevű adatbázis 
bemutatására fókuszál. Az adatbázis ingyenesen elérhető, a WIPO PATENTSCOPE-ban tárolt 71 millió nemzetközi szabványának egy része képezi az adatok alapját. Az adatbázis összesen 29 domént és 311 aldomént fed le. A terminusok ontológiailag szervezettek, egy fogalomhoz egy bejegyzés tartozik. $\mathrm{Az}$ adatbázis egy nyelvi, továbbá újdonságként egy ontológiai, fogalmi térképes keresőfelülettel is rendelkezik. Az adatbázist évente kb. 25 ezer terminus hozzáadásával bővítik, a terminológiai munkába a WIPO belső fordítóit is belevonják, így összesen több mint 70 fő foglalkozik (részben) az adatbázis fejlesztésével. A szabványok fordításának megkönnyítésére 2016 óta neurális gépi fordítórendszert alkalmaznak. Jordi Bover a katalán TERMCAT munkatársa előadásában röviden bemutatta a terminológiai adatbázisukat, a Cercaterm-et, mely jelenleg 350000 bejegyzést tartalmaz. Előadásában ismertette a TERMCAT munkásságát, valamint az újonnan létrehozott tematikus weboldalaikat. A tematikus weboldalakon keresztül az adott szakterület munkatársai naprakész információkat kaphatnak a katalán terminológia szakterületükre vonatkozó változásáról, valamint a számukra érdekes információkhoz egyszerübben hozzáférhetnek. A szekció utolsó előadója Delyth Prys, a walesi Bangor Egyetem oktatója volt. Előadásában a walesi terminológia és terminológiai fejlesztések megosztására fókuszált. A papír alapú szótárak a szélesebb körű elérés érdekében kezdetben $\mathrm{CD}$ formátummal bővültek, majd webszótár funkciót is kaptak, mára pedig letölthető appok formájában is a felhasználóközönség részére állnak. Véleménye szerint, a széles körü elérés érdekében, a felhasználókat több csatornán keresztül kell elérni, így van lehetőség arra, hogy minél többen használják ezeket a terminológiai segédeszközöket.

Az utolsó szekció a terminusok sikerességének mérését járta körül. Az első előadó Iker Etxebeste az UZEI terminológiai osztályának vezetője, a baszk nyelvű jogi szövegek terminológiai mérését járta körül. A vizsgálat elvégzéséhez 552 fogalmat és 1333 terminust határoztak meg és kategorizálták azokat használatra ajánlott és használatra nem ajánlott kategóriákba. Az elemzés eredményeként arra jutottak, hogy a szövegekben $90 \%$-os volt az ajánlott terminusok aránya. Jelenleg egy automatikus lexikai ellenőrző szoftveren dolgoznak, amely kétnyelvű szövegek esetében működne. Ez feldolgozza a párhuzamos szövegeket, felismeri a forrásnyelvi terminusokat, megkeresi és azonosítja a megfelelő célnyelvi terminust, majd abban az esetben, ha nincs találat, jelzi a felhasználónak a kontextus kiemelésével. Adam Renwick előadása módszertani kérdéseket járt körül. Előadásában arra fókuszált, hogy milyen módon mérhetjük a terminusok meghonosodottságát a szövegeket vizsgálva. A szövegek vizsgálatát tekintve foglalkozott a szövegtípusok elkülönítésének szükségességével, az előfordulás mérésének nehézségeivel (adott terminust egy szöveg sokszor, vagy sok szöveg, de kevés alkalommal tartalmazza). Előadásában arra a megállapításra jutott, hogy a terminológiai korpuszt objektív módon kell összeállítani, máskülönben a kutatás nem lesz megismételhető. A szekció utolsó előadója Gabrielle Le Tallec Lloret volt, aki betegség miatt sajnos nem tudott részt venni a konferencián, így előadását felolvasták. Az előadás a francia nyelvű foglalkozásnevek feminizálódását járta körül. A nőnemű alakok létrehozása érdekében egy 2624 hímnemű bejegyzésből álló listát készítettek, melyen 313 bejegyzésre redukál- 
tak fontossági szempontok alapján. Jelenleg is ezekkel dolgoznak, a megfelelő nőnemű alakok kialakítása érdekében.

Külön élményt jelentett a résztvevők számára, hogy az UZEI szervezésében egy speciális baszk nyelvtörténeti kulturális városnéző sétán vehettek részt, amely a baszk nyelvi központ vezetőjének előadásával zárult.

Az előadások diái és azok videofelvételei a konferencia honlapján (http:// www.uzei.eus/eaft2018/presentations/) elérhetők, valamint az előadások kiadvány formában is meg fognak jelenni.

\title{
FORDÍTÁSTUDOMÁNY
}

\author{
Tanulmányok az irásbeli és szóbeli nyelvi közvetités \\ elmélete, gyakorlata és oktatása témaköréből
}

(ISSN 14197480 [nyomtatott])

A folyóirat webhelye: https://ojs3.mtak.hu/index.php/fordtud/ (megjelenik évente két alkalommal - tavasszal és ősszel)

Elérhető: www.elteftt.hu/kiadványok

Főszerkesztő:

\section{KLAUDY KINGA}

E-mail: klaudy.kinga@btk.elte.hu

A FORDíTÁSTUdOMÁNY magyar nyelvü, lektorált tudományos folyóirat, amelyet az ELTE BTK Fordító- és Tolmácsképző Tanszéke indított 1999-ben. A folyóirat évente kétszer jelenik meg, alcíme: Tanulmányok az irásbeli és szóbeli nyelvi közvetités elmélete, gyakorlata és oktatása témaköréböl.

A FORDÍTÁSTUDOMÁNY célja, hogy magyar nyelvü szakmai fórumot teremtsen egy dinamikusan fejlődő, új interdiszciplináris tudományos kutatási terület művelői számára. A folyóirat a fordítástudományt a lehető legtágabban értelmezi. Helyet kap benne a fordítói és tolmácsolási gyakorlat bármely válfajának rendszerező és elméleti megközelítése. Az általános fordításelméleti tanulmányokon kívül nagy teret szentel a leíró fordításkutatásnak, a párhuzamos korpuszokon alapuló empirikus vizsgálatoknak, a fordítás és tolmácsolás oktatásának. Rendszeresen közöl mühelytanulmányokat, fordításkritikát. Figyelemmel kíséri a fordítástudományi, valamint a fordítástudományhoz kapcsolódó publikációkat, ezekről hosszabb elemző kritikákat közöl a Recenziók rovatban, és rövidebb ismertetéseket a Szemle rovatban.

A kéziratokat kérjük elektronikus formában az alábbi címre küldeni: Klaudy Kinga, föszerkesztő. E-mail: klaudy.kinga@btk.elte.hu.

A tanulmányokhoz kérünk 150 szavas angol és magyar kivonatot csatolni, öt-öt kulcsszóval. A beérkezett cikkeket először a szerkesztőbizottság bírálja el abból a szempontból, hogy illeszkednek-e a folyóirat profiljába. Ezután következik a névtelen lektorálási folyamat, amelyben a lektorok elfogadásra, átdolgozásra vagy elutasításra javasolhatják a kéziratot.

A 2005. évfolyam második számától a folyóirat hozzáférhető PDF formátumban az FTT honlapján: www.elteftt.hu. A 2019. évfolyam második számától teljes mértékben átállunk a nyílt hozzáférésre és a folyóirat ezentúl csak on-line formában lesz olvasható. Könyvtárak számára a korábbi papíralapú folyóiratszámokat a Fordító- és Tolmácsképző Tanszék ingyenesen pótolni tudja.

Információ: Bertalan Zoltánné ELTE BTK FTT, Budapest 1088, Múzeum krt. 4., F épület I. emelet 3-4. Telefon: 4116500/5894, E-mail: bertalan.zoltanne@btk.elte.hu. 